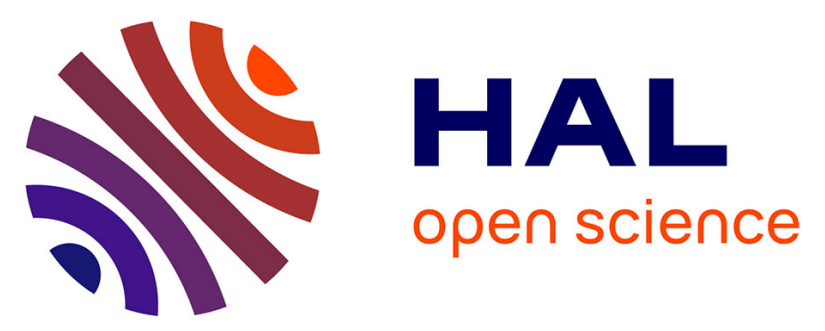

\title{
Activation of a (cyclooctadiene) rhodium(i) complex supported by a chiral ferrocenyl phosphine thioether ligand for hydrogenation catalysis: a combined parahydrogen NMR and DFT study
}

Ekaterina Kozinets, M. Fekete, O. A. Filippov, N. V. Belkova, E. S. Shubina, Rinaldo Poli, S. B. Duckett, E. Manoury

\section{To cite this version:}

Ekaterina Kozinets, M. Fekete, O. A. Filippov, N. V. Belkova, E. S. Shubina, et al.. Activation of a (cyclooctadiene) rhodium(i) complex supported by a chiral ferrocenyl phosphine thioether ligand for hydrogenation catalysis: a combined parahydrogen NMR and DFT study. Dalton Transactions, 2013, 42 (32), pp.11720-11730. 10.1039/C3DT51429C . hal-00995633

\section{HAL Id: hal-00995633 https://hal.science/hal-00995633}

Submitted on 3 Mar 2021

HAL is a multi-disciplinary open access archive for the deposit and dissemination of scientific research documents, whether they are published or not. The documents may come from teaching and research institutions in France or abroad, or from public or private research centers.
L'archive ouverte pluridisciplinaire HAL, est destinée au dépôt et à la diffusion de documents scientifiques de niveau recherche, publiés ou non, émanant des établissements d'enseignement et de recherche français ou étrangers, des laboratoires publics ou privés. 


\title{
Activation of a (cyclooctadiene)rhodium(I) complex supported by a chiral ferrocenyl phosphine thioether ligand for hydrogenation catalysis: a combined parahydrogen NMR and DFT study.
}

\author{
Ekaterina M. Kozinets, ${ }^{a, b, c}$ Marianna Fekete, ${ }^{d}$ Oleg A. Filippov, ${ }^{c}$ Natalia V. Belkova*, ${ }^{c}$ Elena S. Shubina, ${ }^{c}$ \\ ${ }_{5}$ Rinaldo Poli*, ${ }^{a, b, e}$ Simon B. Duckett*, ${ }^{d}$ and Eric Manoury ${ }^{* a, b}$
}

\author{
Received (in XXX, XXX) Xth XXXXXXXXX 20XX, Accepted Xth XXXXXXXXX 20XX \\ DOI: 10.1039/b000000x
}

The reaction of $\left[\mathrm{RhCl}\left(\mathrm{P}, \mathrm{S}^{t} \mathrm{Bu}\right)(\mathrm{COD})\right](\mathbf{1})$ or $\left[\mathrm{Rh}\left(\mathrm{P}, \mathrm{S}^{t} \mathrm{Bu}\right)(\mathrm{COD})\right] \mathrm{BF}_{4}(\mathbf{2})$ where $\left(\mathrm{P}, \mathrm{S}^{t} \mathrm{Bu}\right)$ is $\mathrm{CpFe}\left[\eta^{5}-1,2-\right.$ $\left.\mathrm{C}_{5} \mathrm{H}_{3}\left(\mathrm{PPh}_{2}\right)\left(\mathrm{CH}_{2} \mathrm{~S}^{t} \mathrm{Bu}\right)\right]$ with $\mathrm{H}_{2}$ in $\mathrm{MeOH}$ gives rise to COD hydrogenation and formation of a solvent-

10 stabilized product. The formation of hydride species cannot be observed in view of a very rapid H/D exchange between $\mathrm{H}_{2}$ and the solvent. Introduction of pyridine or acetonitrile slows down this exchange process and allows observation of diastereometric dihydride complexes, $\left[\mathrm{Rh}\left(\mathrm{P}, \mathrm{S}^{t} \mathrm{Bu}\right)(\mathrm{H})_{2}(\mathrm{~L})_{2}\right]^{+}$, the stereochemistry of which was fully elucidated. The hydride site exchange rates have been derived from EXSY NMR experiments and used, with assistance from DFT calculation, to elucidate the isomerization 15 and site exchange mechanisms.

\section{Introduction}

Square planar $d^{8}$ complexes of $\mathrm{Rh}^{\mathrm{I}}$ and $\operatorname{Ir}^{\mathrm{I}}$ are commonly employed as catalysts in a variety of hydrogenation processes. The most popular examples include the so-called "Wilkinson's 20 catalyst", $\left[\mathrm{RhCl}\left(\mathrm{PPh}_{3}\right)_{3}\right],{ }^{1}$ and the cation $\left[\operatorname{Ir}(\mathrm{COD})(\mathrm{L})_{2}\right]^{+}(\mathrm{L}=$ $\mathrm{PPh}_{3}, \mathrm{PMePh}_{2}$, py), the latter of which displays high activities even with relatively hindered C-C double bonds. ${ }^{2}$ Complexes of type $[\mathrm{MCl}(\text { diene })]_{2}$ or $\left[\mathrm{M}(\text { diene })_{2}\right]^{+}[\mathrm{M}=\mathrm{Rh}$ or $\mathrm{Ir}]$, and particularly those of iridium, have also proven suitable as 25 precatalysts for the ionic hydrogenation of polar substrates such as ketones and imines in the presence of appropriate ligands, mostly diphosphines. ${ }^{3-10}$ A notable example of this is provided by $\mathrm{Ir}^{\mathrm{I}}$-catalyzed imine hydrogenation as used in the multi-ton scale industrial production of the herbicide metolachor. ${ }^{11,12}$

30 In one of our laboratories, chiral ferrocene-based phosphine thioether ligands (P,SR in Scheme 1$)^{13}$ have been developed and shown to be particularly efficient in terms of both activity and enantioselectivity for the hydrogenation of aromatic ketones when combined with $[\operatorname{IrCl}(\mathrm{COD})]_{2}{ }^{14}$ The $\operatorname{Ir}^{\mathrm{I}}$ coordination 35 chemistry of these ligands has also been described. ${ }^{15}, 16$ Since the initial studies that were aimed at generating and characterizing the catalytically active species met with difficulty, our attention has more recently turned to the analogous (P,SR)-based rhodium complexes, inspired by reports of the isolation and 40 characterization of related diphosphine-based complexes at the pre-catalyst activation stage. ${ }^{17-20} \mathrm{We}$ have thus synthesized and characterized complexes of type $[\mathrm{RhCl}(\mathrm{P}, \mathrm{SR})($ diene $)]$ and $[\mathrm{Rh}(\mathrm{P}, \mathrm{SR})(\text { diene })]^{+} \mathrm{BF}_{4}^{-} \quad($ diene $=$ cyclooctadiene, $\mathrm{COD}$; norbornadiene, NBD), ${ }^{21}$ as shown in Scheme 1. These complexes

45 have been demonstrated to act as both structural and functional mimics of the analogous Ir systems, although they show lower catalytic activity and selectivity. ${ }^{22} \mathrm{We}$ considered it of interest to investigate the phenomenon of precatalyst activation by use of parahydrogen NMR.

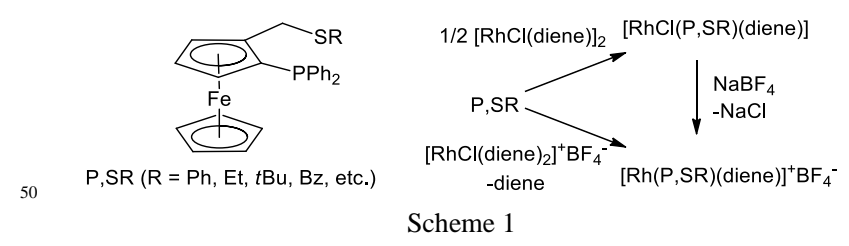

The parahydrogen method has been used extensively to probe reaction mechanisms by enabling the detection of low concentration species such as intermediates in catalysis. ${ }^{23,}{ }^{24} \mathrm{It}$ 55 was first successfully employed by Weitekamp, ${ }^{25}$ and later Eisenberg and Bargon, ${ }^{26}$ but is now being employed much more widely as a consequence of the potential that hyperpolarization methods offer to magnetic resonance imaging and hence health care. ${ }^{27}$ When this approach is used in conjunction with DFT the 60 synergy of the two methods becomes readily apparent as hitherto unseen species are not only predicted but firmly characterized in solution. Such studies have already been used to rationalize a series of reactions involving ruthenium clusters ${ }^{28-30}$ where they can play a key role by helping with chemical shift and coupling 65 assignments. Furthermore they have established a definitive opportunity to examine the role of electronic states in the oxidative addition of $\mathrm{H}_{2}$ to a series of 16 electron ruthenium complexes $^{31,32}$ and aided in the understanding of hydrogenation catalysis by a range of palladium complexes, ${ }^{33,34}$ and even to 70 detect unexpected $\mathrm{CH}$ bond activation products in conjunction with the well-known complex $\mathrm{W}\left(\mathrm{N}_{2}\right)_{2}$ (dppe $)_{2}{ }^{35}$

In this contribution, we address the stoichiometric reactivity of two representative compounds containing the same $\left(\mathrm{P}, \mathrm{S}^{t} \mathrm{Bu}\right)$ ligand, $\left[\mathrm{RhCl}\left(\mathrm{P}, \mathrm{S}^{t} \mathrm{Bu}\right)(\mathrm{COD})\right](\mathbf{1})$ and $\left[\mathrm{Rh}\left(\mathrm{P}, \mathrm{S}^{t} \mathrm{Bu}\right)(\mathrm{COD})\right]^{+} \mathrm{BF}_{4}$ 75 (2), towards $\mathrm{H}_{2}$ through the eyes of parahydrogen NMR, complemented by DFT calculations.

\section{Experimental Section}

\section{General}

All the reactions described here and the complex purifications 80 were carried out under argon using high vacuum line or Schlenk 
line techniques. The $\mathrm{Rh}$ complexes $\left[\mathrm{RhCl}\left(\mathrm{P}, \mathrm{S}^{t} \mathrm{Bu}\right)(\mathrm{COD})\right](\mathbf{1})$ and $\left[\mathrm{Rh}\left(\mathrm{P}, \mathrm{S}^{t} \mathrm{Bu}\right)(\mathrm{COD})\right] \mathrm{BF}_{4} \quad(\mathbf{2}) \quad$ were synthesized from 2diphenylphosphino-( $t$-butylthiomethyl)ferrocene $\left(\mathrm{P}, \mathrm{S}^{t} \mathrm{Bu}\right)$ and $[\mathrm{RhCl}(\mathrm{COD})]_{2}$ or $\left[\mathrm{Rh}(\mathrm{COD})_{2}\right] \mathrm{BF}_{4}$ according to the published 5 procedure. $^{21}$

\section{NMR experiments}

NMR measurements were made using NMR tubes that were fitted with J. Young's valves and solutions were degassed on a high vacuum line prior to $\mathrm{H}_{2}$ addition. The samples were 10 prepared in a glovebox by addition of the specified deuterated solvents to the solid complex in the NMR tube. For the $p-\mathrm{H}_{2}$ induced polarization (PHIP) experiments, hydrogen enriched in the para spin state was prepared by cooling $\mathrm{H}_{2}$ to $36 \mathrm{~K}$ over the paramagnetic catalyst $\mathrm{Fe}_{2} \mathrm{O}_{3}$ which was doped on silica. ${ }^{23}$, 24, 36 15 All the resulting NMR studies were then carried out with sample concentrations of approximately $4.6 \mathrm{mM}$ and all spectra were recorded on a Bruker Avance III 400 NMR spectrometer. ${ }^{1} \mathrm{H}$ NMR chemical shifts are reported in ppm relative to the residual ${ }^{1} \mathrm{H}$ signal of the solvent which for $\mathrm{CHD}_{2} \mathrm{OD}$ is $\delta 3.31$ and for ${ }_{20} \mathrm{CDHCl}_{2}$ is $\delta$ 5.37. Further details can be found in the supplementary information.

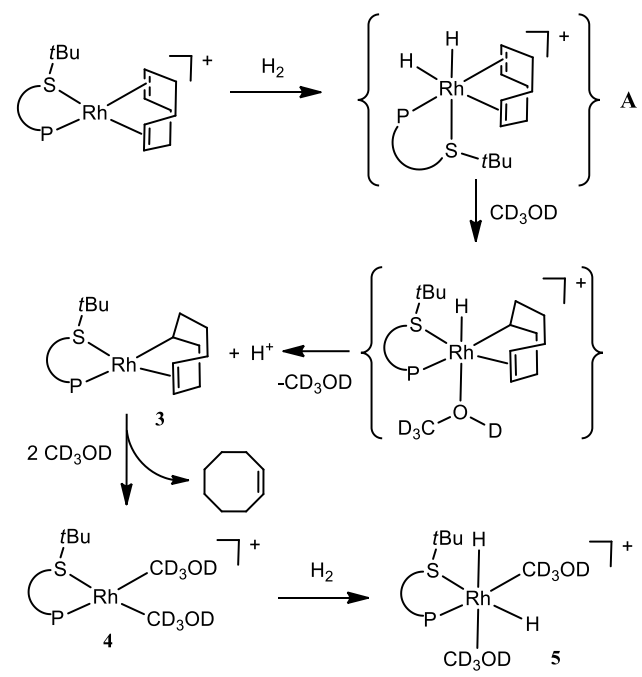

Scheme 2

\section{Computational details}

25 Calculations were performed with the Gaussian09 package $^{37}$ using the $\mathrm{B} 3 \mathrm{LYP}^{38,} 39$ and $\mathrm{M}^{30} 6^{40}$ functionals under the DFT approach. All carbon and hydrogen atoms were described with the $6-31 \mathrm{G}(\mathrm{d}, \mathrm{p})$ basis set, whereas the $6-31++\mathrm{G}(\mathrm{d}, \mathrm{p})$ basis set was applied to the atoms of ligands involved in the bonding with $\mathrm{Rh}$ 30 (P, S atoms, hydride ligands, $\mathrm{OH}$ group of methanol and $\mathrm{N}$ atoms of pyridine and acetonitrile). Effective core potentials (ECP) and its associated SDD basis set ${ }^{41-44}$ supplemented with f-polarization functions $(\operatorname{SDD}(\mathrm{f}))^{45}$ were applied for the $\mathrm{Rh}$ and $\mathrm{Fe}$ atoms. Geometry optimizations were performed without any ligand 35 simplification for the cationic $\left[\mathrm{Rh}\left(\mathrm{P}, \mathrm{S}^{t} \mathrm{Bu}\right) \mathrm{L}_{2}\right]^{+}$and $\left[\mathrm{Rh}\left(\mathrm{P}, \mathrm{S}{ }^{t} \mathrm{Bu}\right)(\mathrm{H})_{2} \mathrm{~L}_{2}\right]^{+}$complexes $\left(\mathrm{L}=\right.$ pyridine, $\left.\mathrm{CH}_{3} \mathrm{OH}, \mathrm{CH}_{3} \mathrm{CN}\right)$. Frequency calculations were performed for all optimized complexes in the gas phase and reported without use of scaling factors. The nature of all the stationary points on the potential ${ }^{40}$ energy surfaces was confirmed by a vibrational analysis. ${ }^{46}$
Transition state (TS) structures showed only one negative eigenvalue in their diagonalized force constant matrices, and their associated eigenvectors were confirmed to correspond to the motion along the reaction coordinate under consideration using 45 the Intrinsic Reaction Coordinate (IRC) method. ${ }^{47}$

\section{Results and Discussion}

\section{(a) NMR experiments}

\section{In $\mathrm{CD}_{3} \mathrm{OD}$ without additives}

The addition of $p-\mathrm{H}_{2}$ to $d_{4}$-methanol solutions of either ${ }_{50}\left[\mathrm{RhCl}\left(\mathrm{P}, \mathrm{S}^{t} \mathrm{Bu}\right)(\mathrm{COD})\right](\mathbf{1})$ or $\left[\mathrm{Rh}\left(\mathrm{P}, \mathrm{S}^{t} \mathrm{Bu}\right)(\mathrm{COD})\right] \mathrm{BF}_{4}(\mathbf{2})$, over the temperature range $233-298 \mathrm{~K}$, failed to result in the observation of any detectable hydride containing species. There was, however, evidence for a common slow reaction (ca. 18\% conversion in 20 minutes at $243 \mathrm{~K}$ ) which transformed the $\eta^{2}-\eta^{2}$ ${ }_{55}$ COD ligand into a $\kappa^{3}(\sigma: \pi)$ cyclooct-4-enyl ligand and generated the new proton loss complex, 3, (Scheme 2) in very small amounts. The $\kappa^{3}$-ligand in this complex is characterized by features at $\delta 4.62,1.54$ and 2.15, see Figures S1 and S2. This suggests that while slow $\mathrm{H}_{2}$ addition to the $\mathrm{Rh}$ centre occurs, 60 rapid reaction transforms the resulting dihydride into 3 . This process is followed by reprotonation to form the corresponding alkene after hydride migration as shown in Scheme 2. The liberation of either $\mathrm{HCl}$ or $\mathrm{HBF}_{4}$ is proposed to give 3. Sola et al. have reported a related $\mathrm{H}_{2}$ addition to the complex [ $\operatorname{Ir}(\mathrm{COD})$ $\left.{ }_{65}\left(\mathrm{NCCH}_{3}\right)\left(\mathrm{PMe}_{3}\right)\right] \mathrm{BF}_{4}$, where the initial dihydride product $\left[\mathrm{Ir}(\mathrm{H})_{2}\right.$ $\left.(\mathrm{COD})(\mathrm{MeCN})\left(\mathrm{PMe}_{3}\right)\right] \mathrm{BF}_{4}$ (in $\mathrm{CH}_{2} \mathrm{Cl}_{2}$ ) reacts with $\mathrm{MeCN}$ to form the monohydride product $\left[\mathrm{IrH}\left(1-\kappa-4,5-\eta-\mathrm{C}_{8} \mathrm{H}_{13}\right)\left(\mathrm{NCCH}_{3}\right)_{2}-\right.$ $\left(\mathrm{PMe}_{3}\right) \mathrm{BF}_{4}$. In this case, these species could be isolated and fully characterized. ${ }^{48}$ We note that $\mathbf{3}$ is related to this Ir system by the 70 formal loss of a proton. Given that $\mathrm{Rh}^{\mathrm{III}}$ hydride complexes are known to be less stable than their IrII analogues this transformation is not unexpected.

At $253 \mathrm{~K}$ the generation of cyclooctene was revealed by its characteristic ${ }^{1} \mathrm{H}$ NMR resonance at $\delta 1.21$, which rapidly 75 increases in intensity over the time scale of 17 minutes (Figure $\mathrm{S} 2$ ). This demonstrates that the initial $\mathrm{H}_{2}$ addition to $\mathbf{1}$ or $\mathbf{2}$ proceeds at $253 \mathrm{~K}$. When the temperature was raised to $263 \mathrm{~K}$ the formation of cyclooctane was also observed through its characteristic singlet at $\delta 1.50$. Hydride resonances were not 80 observed at any time during this reaction. However, the residual $\mathrm{OH}$ signal of methanol and the $\mathrm{H}_{2}$ signal show dramatic temperature dependence, coalescing at $263 \mathrm{~K}$ thereby suggesting the rapid interchange of these sites, presumably through the formation of transient, non observable hydride species.

85 At $273 \mathrm{~K}$ the deuteration of the $\mathrm{H}_{2}$, forming $\mathrm{HD}$ becomes evident (Figure S3). In addition, the phenyl proton signals for the phosphine become more complicated in appearance at this point. This reaction monitoring demonstrated the instability of $\mathbf{3}$ and suggested that the ultimate formation of a bis(solvent) adduct, ${ }_{90}\left[\mathrm{Rh}\left(\mathrm{P}, \mathrm{S}^{t} \mathrm{Bu}\right)(\mathrm{MeOH})_{2}\right]^{+}, \quad 4$, takes place even though direct evidence for the production of this complex could not be obtained. Further $\mathrm{H}_{2}$ oxidative addition to yield a putative dihydride species $\mathbf{5}$ appears excluded by the absence of hydride signals in this experiment (however, see additional discussion ${ }_{95}$ below). Monitoring the reaction carried out with regular $\mathrm{H}_{2}$ at 5 bar pressure and room temperature by ${ }^{31} \mathrm{P}$ NMR did not result in the appearance of any new resonance, in fact only the signal for 


\section{Cite this: DOI: 10.1039/c0xx00000x}

\section{wWw.rsc.org/xxxxxx}

ARTICLE TYPE

unreacted starting material could be seen even after $7 \mathrm{~h}$. After 3 days the starting material was completely consumed and the new NMR spectrum shows very few small resonances, the major one being a doublet at $\delta 43.9\left(\mathrm{~J}_{\mathrm{PRh}}=134.1 \mathrm{~Hz}\right)$. These data suggest 5 that $\mathbf{4}$ is not stable.

Our attempts to isolate the final product of this reaction in a crystalline form have so far not succeeded. Heller et al. have recently reported the successful generation and isolation of the complex $\left[\mathrm{Rh}(\mathrm{BINAP})(\mathrm{MeOH})_{2}\right]^{+}$by hydrogenation of $10[\mathrm{Rh}(\mathrm{BINAP})(\mathrm{COD})]^{+}$or $[\mathrm{Rh}(\mathrm{BINAP})(\mathrm{NBD})]^{+}$in methanol, although no reaction intermediates were observed in those cases. $^{18}$

When this reaction was carried out in $\mathrm{CD}_{2} \mathrm{Cl}_{2}$ using 2 , reaction with $p-\mathrm{H}_{2}$ was evident at temperatures down to $233 \mathrm{~K}$. Under 15 these conditions weak signals for a new hydride containing species were detected at $\delta-9.7$ and -23.0 . The high field signal yielded a ${ }^{31} \mathrm{P}$ coupling of $188 \mathrm{~Hz}$ which is indicative of a trans ${ }^{31} \mathrm{P}$ splitting. These two resonances were broad and neither the $\mathrm{J}_{\mathrm{HH}}$ nor the $\mathrm{J}_{\mathrm{RhH}}$ couplings could be quantified. In the 20 corresponding ${ }^{31} \mathrm{P}$ decoupled spectra the $\delta-23.0$ signal yields a $\mathrm{J}_{\mathrm{HH}}$ splitting of $-9 \mathrm{~Hz}$ and a $\mathrm{J}_{\mathrm{RhH}}$ splitting of $20 \mathrm{~Hz}$. The signals for this species were too weak to enable its characterisation but the hydride trans to phosphine deduction is confirmed by the large coupling and a species such as $\mathbf{A}$ in Scheme 2 is possible. 25 The addition of $1 \mu \mathrm{l}$ of $\mathrm{MeOH}$ to this solution suppressed the observation of these signals.

Two key observations outlined above (the coalescence of the $\mathrm{MeOH}$ and $\mathrm{H}_{2}$ signals, and $\mathrm{H} / \mathrm{D}$ exchange between these two molecules) lead us to speculate on the mechanism associated with

30 these phenomena, which are obviously related to the same process, occurring rapidly on the NMR timescale. Two possible pathways are indicated in Scheme 3. In pathway $a, \mathrm{H}_{2}$ oxidative addition yields a $\mathrm{Rh}^{\mathrm{III}}$ dihydride species $\mathbf{5}$ that would be sufficiently acidic to release a proton to the solvent and yield a

${ }_{35} \mathrm{Rh}^{\mathrm{I}}$ monohydride intermediate 6 . Reversal of all steps with implication of deuteron incorporation is a consequence of this exchange pathway. In the alternative pathway $b, \mathrm{H}_{2}$ replaces a methanol ligand to yield an $\mathrm{H}_{2}$ complex (non-classical dihydride) 7, which is then deprotonated by the solvent to yield the same 40 monohydride complex $\mathbf{6}$ as detailed above. Both of these pathways can be imagined to occur via initial reaction which places the hydride trans to $S$ (as shown in Scheme 3) or in the alternative position trans to $\mathrm{P}$ which is not illustrated. Incidentally, the lack of observation of a hydride resonance under 45 these conditions does not exclude the fact that the most stable species (at least at low temperatures) is indeed a mono- or dihydride complex, since such a species would exist primarily in the form of a deuteride and would therefore be unobservable in the hydride region of the ${ }^{1} \mathrm{H}$ NMR spectrum.

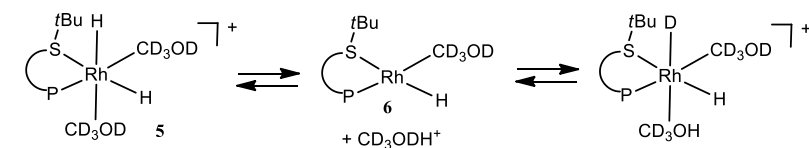

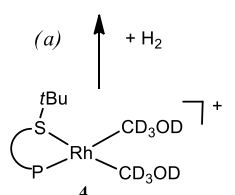

(b) $\downarrow+\mathrm{H}_{2}$

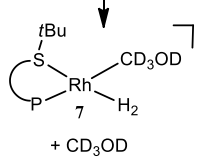

$+\mathrm{CD}_{3} \mathrm{OD}$
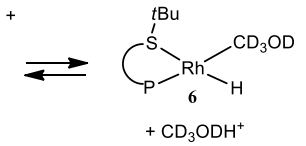

Scheme 3

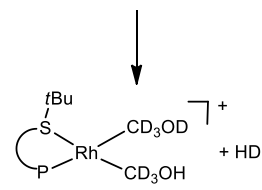

\section{In $\mathrm{CD}_{3} \mathrm{OD}$ in the presence of pyridine}

When the analogous reactions of either $\mathbf{1}$ or $\mathbf{2}$ with $\mathrm{H}_{2}$ were 55 carried out in the presence of pyridine at low temperature (233 $283 \mathrm{~K}$ ), on the other hand, two common and dominant hydride containing products formed. For example, when a $d_{4}$-methanol solution of 1 was prepared which contained a 75-fold excess of pyridine (75 equiv) and the resulting reaction with $p-\mathrm{H}_{2}$ 60 monitored by ${ }^{1} \mathrm{H}$ NMR spectroscopy at $233 \mathrm{~K}$, four PHIP enhanced hydride signals were observed at $\delta-13.1, \delta-14.3, \delta$ 17.2 and $\delta-17.6$. These hydride ligand signals all contained antiphase features due to their formation from $p-\mathrm{H}_{2}$ that are associated with their common $\mathrm{J}_{\mathrm{HH}}$ coupling in addition to in${ }_{65}$ phase splittings due to further couplings to a single rhodium and single phosphorus centre. A more complete NMR monitoring of this reaction was undertaken after warming the sample to $263 \mathrm{~K}$, during which process the NMR spectral features did not change. The hydride region of the resulting ${ }^{1} \mathrm{H}$ NMR spectrum is shown 70 in Figure 1a. The $J_{P H}$ coupling values are all consistent with cis hydride phosphorus ligand arrangements. In addition, in the corresponding ${ }^{1} \mathrm{H}-{ }^{31} \mathrm{P}$ HMQC NMR spectrum (Figure $1 \mathrm{~b}$ ), the $\delta$ $-13.1\left(\mathrm{~J}_{\mathrm{HH}}=-13 \mathrm{~Hz}, \mathrm{~J}_{\mathrm{RhH}}=24 \mathrm{~Hz}\right)$ and $\delta-17.6\left(\mathrm{~J}_{\mathrm{HH}}=-13 \mathrm{~Hz}, \mathrm{~J}_{\mathrm{RhH}}\right.$ $=19 \mathrm{~Hz}$ ) signals proved to couple to a single ${ }^{31} \mathrm{P}$ centre that was 75 located at $\delta 47.9$ and appeared with a $\mathrm{J}_{\mathrm{RhP}}$ of $140.0 \mathrm{~Hz}$. These resonances therefore arise from groups within the same complex (8). In a similar manner the $\delta-14.3\left(\mathrm{~J}_{\mathrm{HH}}=-10 \mathrm{~Hz}, \mathrm{~J}_{\mathrm{RhH}}=24 \mathrm{~Hz}\right)$ and $\delta-17.2\left(\mathrm{~J}_{\mathrm{HH}}=-10 \mathrm{~Hz}, \mathrm{~J}_{\mathrm{RhH}}=20 \mathrm{~Hz}\right)$ signals arise from a second species (9) where now the connected ${ }^{31} \mathrm{P}$ resonance 80 appears at $\delta 45.0$ with a $\mathrm{J}_{\mathrm{RhP}}$ of $141.6 \mathrm{~Hz}$. On the basis of the relative hydride resonance peak areas it can be suggested that $\mathbf{8}$ and 9 are formed in a step which shows a kinetic selectivity of approximately 1:4 at $233 \mathrm{~K}$, if it is assumed that these resonances 
Table 1. NMR data for complexes 8 and $\mathbf{9}$ in MeOD at $283 \mathrm{~K}$.

\begin{tabular}{ccccc}
\hline Compound & \multicolumn{1}{c}{$\delta{ }^{1} \mathrm{H}$} & $\delta{ }^{31} \mathrm{P}$ & $\delta{ }^{15} \mathrm{~N}$ & $\delta{ }^{103} \mathrm{Rh}$ \\
\hline $\mathbf{8}$ & $-13.1, \mathrm{dd}, \mathrm{J}_{\mathrm{HH}}=-13 \mathrm{~Hz} ; \mathrm{J}_{\mathrm{RhH}}=24 \mathrm{~Hz}, \mathrm{~J}_{\mathrm{RhP}}=140.0 \mathrm{~Hz}$ & $47.9, \mathrm{~d}$ & $267.6, \mathrm{t}, \mathrm{J}_{\mathrm{PN}}=50 \mathrm{~Hz} ; \mathrm{J}_{\mathrm{NH}}=20 \mathrm{~Hz}$ & $-7390, \mathrm{~d} \mathrm{~J} \mathrm{JhP}_{\mathrm{RhP}}=131 \mathrm{~Hz}$ \\
& $-17.6, \mathrm{dd}, \mathrm{J}_{\mathrm{HH}}=-13 \mathrm{~Hz} ; \mathrm{J}_{\mathrm{RhH}}=19 \mathrm{~Hz}, \mathrm{~J}_{\mathrm{RhP}}=140.0 \mathrm{~Hz}$ & & & \\
$\mathbf{9}$ & $-14.3, \mathrm{dd}, \mathrm{J}_{\mathrm{HH}}=-10 \mathrm{~Hz} ; \mathrm{J}_{\mathrm{RhH}}=24 \mathrm{~Hz}, \mathrm{~J}_{\mathrm{RhP}}=141.6 \mathrm{~Hz}$ & $45.0, \mathrm{~d}$ & $266.2, \mathrm{t}, \mathrm{J}_{\mathrm{PN}}=50 \mathrm{~Hz} ; \mathrm{J}_{\mathrm{NH}}=20 \mathrm{~Hz}$ & $-7268, \mathrm{~d} \mathrm{~J} \mathrm{~J}_{\mathrm{RhP}}=131 \mathrm{~Hz}$ \\
& $-17.2, \mathrm{dd}, \mathrm{J}_{\mathrm{HH}}=-10 \mathrm{~Hz} ; \mathrm{J}_{\mathrm{RhH}}=20 \mathrm{~Hz}, \mathrm{~J}_{\mathrm{RhP}}=141.6 \mathrm{~Hz}$ & & & \\
\hline
\end{tabular}

(a)

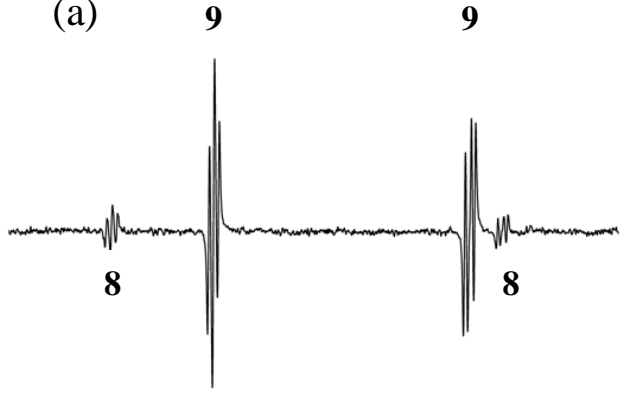

$\begin{array}{lllllll}-13 & -14 & -15 & -16 & -17 & -18 & \text { ppm }\end{array}$

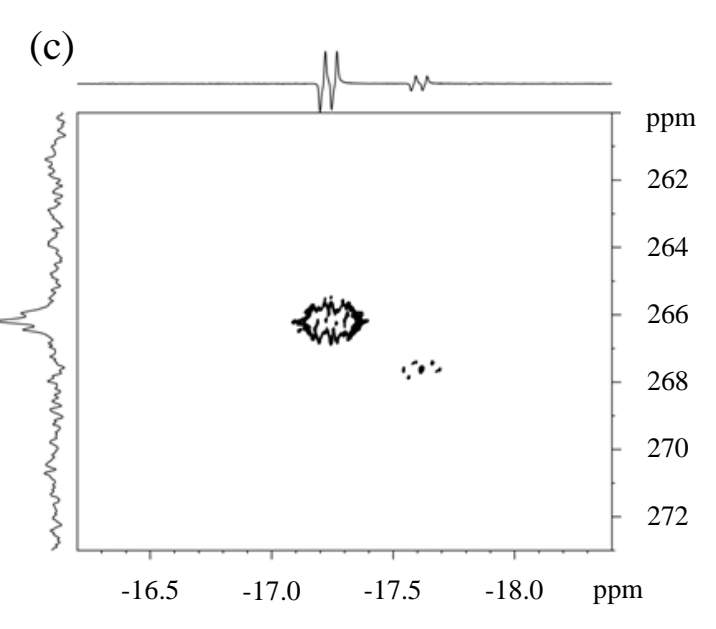

(b)

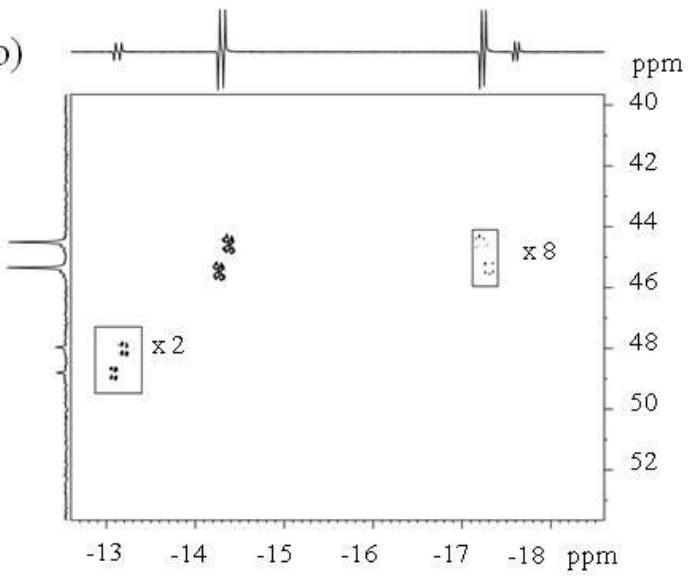

(d)

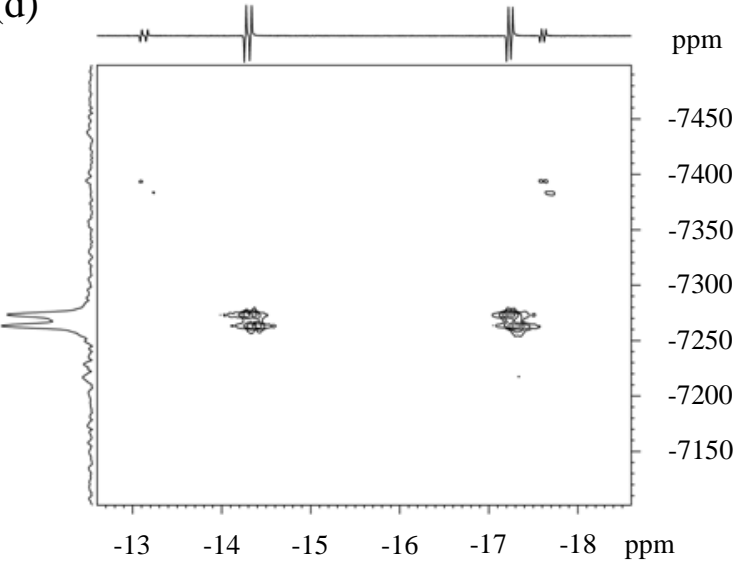

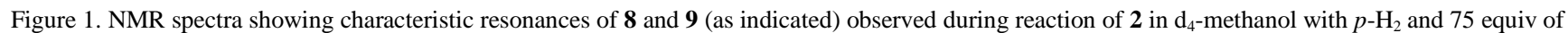
pyridine at $263 \mathrm{~K}$ : (a) $p$ - $\mathrm{H}_{2}$ enhanced ${ }^{1} \mathrm{H}$ NMR spectrum showing the hydride region; (b) ${ }^{1} \mathrm{H}-{ }^{31} \mathrm{P} \mathrm{HMQC}$ NMR spectrum collected using ${ }^{15} \mathrm{~N}$ labeled pyridine; (c) ${ }^{15} \mathrm{~N}$ labeled, ${ }^{1} \mathrm{H}_{-}{ }^{15} \mathrm{~N}$ HMQC NMR spectrum; (d) ${ }^{1} \mathrm{H}-{ }^{103} \mathrm{Rh}$ HMQC NMR spectrum (in (b) the inset boxes reflect vertical expansions of $\mathrm{x} 2$ and $\mathrm{x} 8$ relative to the baseline).

result from PHIP derived magnetic states that are created with identical efficiency. When the temperature is raised to $273 \mathrm{~K}$ the 10 ratio increases to $1: 13$.

Upon increasing the solution temperature to $283 \mathrm{~K}$, no change in the relative size of the PHIP-enhanced signals was observed. However, upon warming to $298 \mathrm{~K}$ and beyond, the hydride signals for $\mathbf{8}$ and $\mathbf{9}$ could no longer be observed. When this 15 experiment was repeated at $263 \mathrm{~K}$ with normal dihydrogen, the ratio of the hydride signals of $\mathbf{8}$ and $\mathbf{9}$ was 1:7. When, on the other hand, the reaction was conducted at room temperature (ca. 15 min between bubbling and recording the NMR spectrum), only the presence of compound $\mathbf{9}$ could be detected, reflecting the 20 greater thermodynamic preference for this isomer.

In order to probe the ligand arrangement in compounds $\mathbf{8}$ and $\mathbf{9}$ further, a ${ }^{15} \mathrm{~N}$ labelled pyridine sample was examined. Now, the two phosphorus signals associated with these two complexes exhibit additional and identical extra splittings of $50 \mathrm{~Hz}$ due to 25 the presence of a resolved trans ${ }^{31} \mathrm{P}_{-}{ }^{15} \mathrm{~N}$ coupling. In the corresponding ${ }^{1} \mathrm{H}_{-}{ }^{15} \mathrm{~N}$ HMQC NMR spectrum (Figure 1c), the hydride signals at $\delta-17.2$ and -17.6 showed strong correlation peaks to ${ }^{15} \mathrm{~N}$ resonances at $\delta 266.2$ and $\delta 267.6$ respectively. In addition, a hydride- ${ }^{15} \mathrm{~N}$ splitting of $20 \mathrm{~Hz}$ was exhibited by the 30 two low field hydride resonances of $\mathbf{8}$ and $\mathbf{9}$. Rhodium signals have also been detected at $\delta-7268$ for $\mathbf{8}$ and $\delta-7389$ for $\mathbf{9}$ through the recording of a ${ }^{1} \mathrm{H}-{ }^{103} \mathrm{Rh}$ HMQC spectrum as shown in Figure 1d.

This information therefore confirms that there are two pyridine 35 ligands attached to the metal centre in $\mathbf{8}$ and $\mathbf{9}$, which are located trans to one hydride and to the phosphine donor. Given the bidentate nature of the P,S ligand it can be further concluded that 
the second hydride ligand in both $\mathbf{8}$ and $\mathbf{9}$ is trans to sulfur. All the NMR data associated with $\mathbf{8}$ and $\mathbf{9}$ resulting from this study are summarized in Table 1 . The similarity of these NMR data suggests that these two products are simply diastereoisomers of 5 one another, differentiated by the ferrocene ligand orientation as shown in Scheme 4. This product geometry indicates that the initial $\mathrm{H}_{2}$ oxidative addition takes place over the $\mathrm{S}-\mathrm{Rh}-\mathrm{C}$ axis.

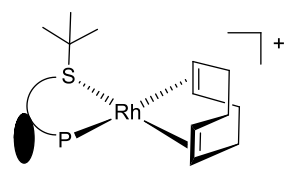

$\mathrm{H}_{2}$ (3 bar)

$\mathrm{MeOD}, 75$ equiv $\mathrm{Py}$ 233 - $283 \mathrm{~K}$

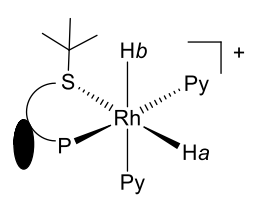

8

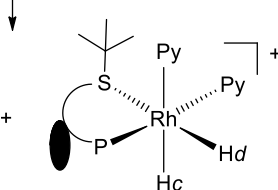

Scheme 4

When an nOe experiment was recorded to probe the hydride site interchange process undergone by these complexes at $273 \mathrm{~K}$ with the 75 fold excess of pyridine, several exchange processes were observed (as revealed in Figure 2). These include a mutual 15 hydride site interchange within 9 which proceeds with an exchange rate constant of $0.785(6) \mathrm{s}^{-1}$ and the interconversion of $\mathbf{9}$ into $\mathbf{8}$ on a slower timescale that places the moving hydride into either site of 8 with rates of $0.167(2) \mathrm{s}^{-1}$ where $\mathrm{H}_{\mathrm{c}}$ becomes $\mathrm{H}_{\mathrm{a}}$ and $\mathrm{H}_{\mathrm{d}}$ becomes $\mathrm{H}_{\mathrm{b}}$ and $0.160(3) \mathrm{s}^{-1}$ where $\mathrm{H}_{\mathrm{c}}$ becomes $\mathrm{H}_{\mathrm{b}}$ and $\mathrm{H}_{\mathrm{d}}$ 20 becomes $\mathrm{H}_{\mathrm{a}}$. Hence there is a limited selectivity in this process. Isomer $\mathbf{8}$ converts into $\mathbf{9}$ on a faster timescale where the observed rate constant is $1.10(1) \mathrm{s}^{-1}$ for the $\mathrm{H}_{\mathrm{a} \rightarrow \mathrm{d}}$ and $\mathrm{H}_{\mathrm{b} \rightarrow \mathrm{c}}$ transformations and 1.19(1) $\mathrm{s}^{-1}$ for the $\mathrm{H}_{\mathrm{a} \rightarrow \mathrm{c}}$ and $\mathrm{H}_{\mathrm{b} \rightarrow \mathrm{d}}$ transformations. The experimental rate constant for hydride site interchange in $\mathbf{8}$ is 25 zero. The overall scheme of hydride site exchange rates is summarized in Scheme 5. Table S1 (Supp. Inf.) shows the list of constraints that were used for the calculation of the exchange rate constants. There was no evidence for hydride exchange into free $\mathrm{H}_{2}$ or $\mathrm{MeOH}$ from 8 or 9 in these experiments which are limited 30 by the timescale of NMR relaxation and contrary to the experiment run in pure $\mathrm{CD}_{3} \mathrm{OD}$ there was no coalescence between the solvent and $\mathrm{H}_{2}$ resonances. We note, however, that the hydride sites of $\mathbf{8}$ and $\mathbf{9}$ are partially deuterated in these experiments. This readily shows up in a ${ }^{31} \mathrm{P}$-decoupled HMQC 35 measurement as isotopically perturbed signals at $\delta-13.1,-14.3$, 17.2 and -17.6 in the corresponding ${ }^{1} \mathrm{H}$ NMR spectrum for the $\mathrm{Rh}(\mathrm{H})(\mathrm{D})$ partners and at $\delta-14.3$ and $\delta-17.2$ for the corresponding ${ }^{31} \mathrm{P}$ signals. Hence, the electronic effect of pyridine coordination stabilizes the dihydride species against 40 deprotonation (cf. Scheme 3).
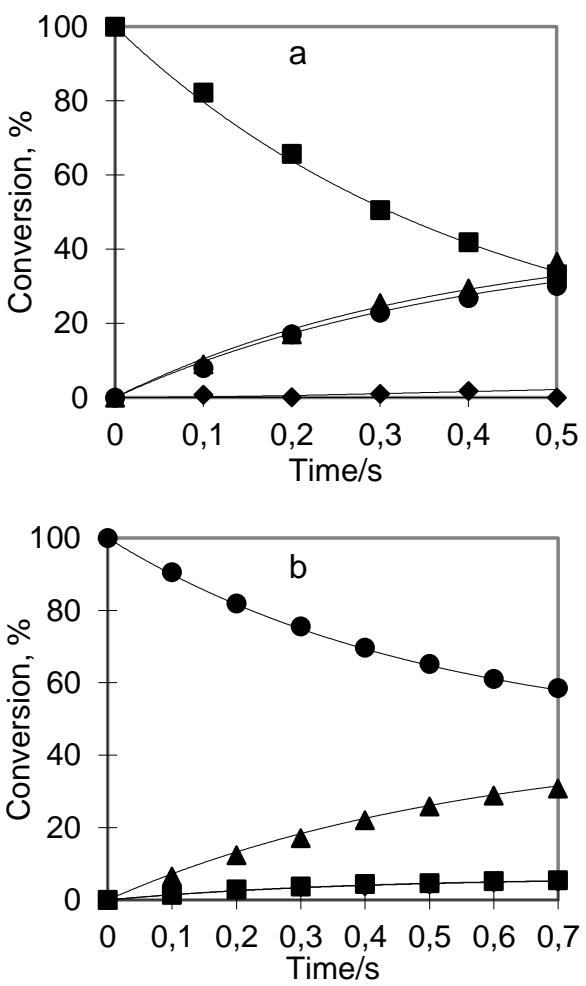

Figure 2. Hydride ligand exchange data for the interconversion of $\mathbf{8}$ and 9 in the presence of 75 -fold excess of py, as probed through the selective 45 excitation of (a) $\mathrm{H}_{\mathrm{a}}$ of $\mathbf{8}$ and (b) $\mathrm{H}_{\mathrm{c}}$ of $\mathbf{9}$, over the defined observation period; the observation points are listed as $\mathrm{H}_{\mathrm{a}}(\boldsymbol{\bullet}), \mathrm{H}_{\mathrm{b}}(\bullet), \mathrm{H}_{\mathrm{c}}(\bullet)$ and $\mathrm{H}_{\mathrm{d}}$

$(\boldsymbol{\Delta})$ as defined in Scheme 4. The solid lines correspond to simulated changes that yield the rate constants in the text.

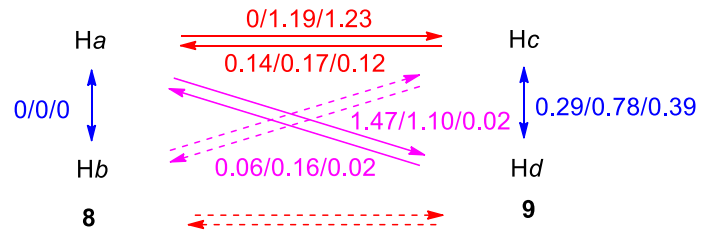

50 Scheme 5. The three numbers on each arrow are the exchange rates in $\mathrm{s}^{-1}$ relative to the solution with an 8 -fold, 75 -fold and 173 -fold excess of py.

While the deuterium label incorporation into the hydride sites is relatively slow, it precludes the measurement of precise rate data as would be required for the assembly of an Eyring plot. ${ }_{55}$ Nonetheless, the interconversion between these species has been defined as occurring without $\mathrm{H}_{2}$ loss. This is reflected in the fact that strong PHIP is only seen when $\mathbf{1}$ or $\mathbf{2}$ are being converted into $\mathbf{8}$ and $\mathbf{9}$. When we monitor these processes with differing amounts of pyridine, changing the $\mathrm{Rh}$ /pyridine ratio from $1: 8$, to $601: 75$, and $1: 173$ we see no change in the relative hydride signal intensities of $\mathbf{8}$ and $\mathbf{9}$. There is, however, a significant effect on the hydride site interchange rate constants.

The rate constant for the mutual hydride site exchange in 9 falls to $0.29 \mathrm{~s}^{-1}$ with an 8 fold excess of pyridine while it is $0.39 \mathrm{~s}$ ${ }_{65}{ }^{1}$ with a 173 fold excess. The kinetic effect of pyridine is therefore complex, first promoting the process and then inhibiting it. A similar trend is observed for the $\mathrm{H}_{d \rightarrow a}$ (and $\mathrm{H}_{c \rightarrow b}$ ) rate from $0.06 \mathrm{~s}^{-1}$ through $0.16 \mathrm{~s}^{-1}$ to $0.02 \mathrm{~s}^{-1}$ and for the $\mathrm{H}_{c \rightarrow a}$ (and $\mathrm{H}_{d \rightarrow b}$ ) rate from $0.14 \mathrm{~s}^{-1}$ through $0.17 \mathrm{~s}^{-1}$ to $0.12 \mathrm{~s}^{-1}$, though the effect 70 here is less dramatic. In contrast, the $\mathrm{H}_{a \rightarrow c}\left(\mathrm{H}_{b \rightarrow d}\right)$ process shows a rate increasing with [py] from $0 \mathrm{~s}^{-1}$ through $1.19 \mathrm{~s}^{-1}$ to $1.23 \mathrm{~s}^{-1}$ 
while the rate of the $\mathrm{H}_{a \rightarrow d}\left(\mathrm{H}_{b \rightarrow d}\right)$ process shows the opposite trend from 1.47 through 1.10 to $0.02 \mathrm{~s}^{-1}$. We can conclude therefore that pyridine plays a role in these processes. All observed hydride site exchange rate constants are collected in 5 Table S3.

The hydride signal at $\delta-17.2$ shows nOe connections to peaks at $\delta 8.71,8.23,4.67,3.84$ and 1.21 , which are due to the ortho proton of a pyridine ligand, the ortho proton of the phosphine, the ferrocenyl group and the ${ }^{t} \mathrm{Bu}$ group in 9 . The second hydride 10 signal in 9 which resonates at $\delta-14.3$ shows through space interactions with protons that give rise to resonances at $\delta 8.71$, $8.31,8.23$ and 6.68 . The extra signal at $\delta 8.31$ is therefore the ortho proton of a second pyridine ligand. In the corresponding ${ }^{1} \mathrm{H}-{ }^{31} \mathrm{P}$ HMQC, the ${ }^{31} \mathrm{P}$ centre which resonates at $\delta 45.0$ connects 15 to two aromatic signals at $\delta 8.23$ and 6.78 . In contrast, the ${ }^{31} \mathrm{P}$ signal of the minor isomer 8 proved to connect with ${ }^{1} \mathrm{H}$ signals at 8.03 and 7.5 in an HMQC measurement. Furthermore, nOe data confirmed that the signal at $\delta-13.1$ in 8 connects with ${ }^{1} \mathrm{H}$ signals at $\delta 8.42$ and 8.03 . The $\delta 8.42$ resonance therefore corresponds to 20 an ortho-pyridine signal. This information has therefore confirmed the assignment shown in Scheme 4. The structure corresponding to $\mathbf{9}$ has therefore the hydride ligand trans to pyridine located on the same side as the ferrocenyl group. When a long range ${ }^{1} \mathrm{H}-{ }^{31} \mathrm{P}$ experiment was recorded, further proton 25 signals were located at $\delta 7.6,4.8$ and 4.2 in 9.

The hydrogenation of the cyclooctadiene ligand is readily evident in these $p-\mathrm{H}_{2}$ enhanced ${ }^{1} \mathrm{H}$ NMR spectra from $253 \mathrm{~K}$. Two sets of polarised signals appear at $\delta 1.53$ and 1.50 due to the $\mathrm{CH}_{2}$ protons of the hydrogenated components of COE. A further 30 resonance is evidenced at $\delta 1.41$ for the backbone signals as described above. In these ${ }^{1} \mathrm{H}$ NMR spectra the corresponding cyclooctane signal appears at $\delta 1.2$ and forms very slowly at 273 $\mathrm{K}$.

When the reaction of the chloride derived precursor $\mathbf{1}$ with 35 normal dihydrogen is monitored in an analogous experiment with only a 15 fold excess of pyridine (instead of 75 in the experiment described above) $\mathbf{5}$ appears as the first formed hydride containing product at $273 \mathrm{~K}$. The problem with this measurement is, however, that it relies on detecting a weak signal from 40 magnetisation that is at thermal equilibrium. When this reaction is repeated with $p-\mathrm{H}_{2}$ weak PHIP-enhanced hydride signals are now seen for a further two species, $\mathbf{1 0}$ and 11, besides those of $\mathbf{8}$ and $\mathbf{9}$ in the resulting NMR spectra at $273 \mathrm{~K}$ (Figure 3). The hydride signals of 10 appear at $\delta-12.3$ and -18.7 with Rh-H couplings of $4525.1 \mathrm{~Hz}$ and $26.8 \mathrm{~Hz}$, respectively, and a common $\mathrm{J}_{\mathrm{HH}}$ coupling of $-5.9 \mathrm{~Hz}$. The hydride ligand signals from species $\mathbf{1 1}$ are, however, much weaker than those of $\mathbf{1 0}$ and appear at $\delta-15.0\left(\mathrm{~J}_{\mathrm{RhH}}=20\right.$, $\left.\mathrm{J}_{\mathrm{HH}}=-9 \mathrm{~Hz}\right)$ and $\delta-17.8\left(\mathrm{~J}_{\mathrm{RhH}}=15, \mathrm{~J}_{\mathrm{HH}}=-9 \mathrm{~Hz}\right)$. The relative ratio of the hydride signals for $\mathbf{1 0}, \mathbf{8}, \mathbf{9}$, and $\mathbf{1 1}$ proved to be ${ }_{50} 0.9: 7.0: 39.6: 1$ at $273 \mathrm{~K}$. In a series of $2 \mathrm{D}$ measurements the $\delta$ 12.3 hydride signal proved to connect with a $\delta 34.3{ }^{31} \mathrm{P}$ resonance where $J_{\mathrm{RhP}}=140 \mathrm{~Hz}$, while the $\delta-15.0$ hydride signal connects with a ${ }^{31} \mathrm{P}$ resonance at $\delta 51.4$ that exhibits a $\mathrm{J}_{\mathrm{RhH}}$ coupling of 148 $\mathrm{Hz}$. The relative intensity of the signals for $\mathbf{1 0}$ and $\mathbf{1 1}$ proved to 55 fall as the excess of pyridine is increased. When labelled pyridine is employed both of the sets of hydride signals show limited broadening but no trans ${ }^{-15} \mathrm{~N}$ coupling is evident. We therefore assign $\mathbf{1 0}$ and $\mathbf{1 1}$ to chloride containing $\left[\mathrm{Rh}(\mathrm{H})_{2}(\mathrm{P}, \mathrm{SR})-\right.$
(pyridine)Cl] as shown in Scheme 6. This deduction is further ${ }_{60}$ supported by the fact that while the relative intensities of the signals for $\mathbf{8}$ and $\mathbf{9}$ seem to remain constant regardless of the [py] those for $\mathbf{1 0}$ and $\mathbf{1 1}$ drop as the [py] increases.

When a series of EXSY measurements were undertaken to examine the dynamic behaviour of this complex reaction system, ${ }_{65}$ interconversion between $\mathbf{1 0}, \mathbf{8}$ and $\mathbf{9}$ was evident with the signals for $\mathbf{1 1}$ proving to be too weak to monitor.

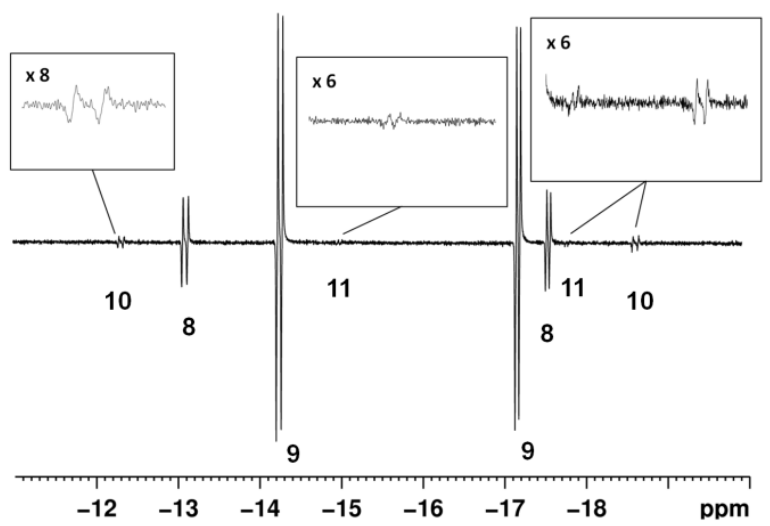

Figure 3. NMR spectra showing characteristic hydride resonances of $\mathbf{8 , 9}$, 10 and 11 (as indicated) observed during reaction of $\mathbf{1}$ in $\mathrm{d}_{4}$-methanol with $p-\mathrm{H}_{2}$ and 45 -fold excess of pyridine at $273 \mathrm{~K}$.

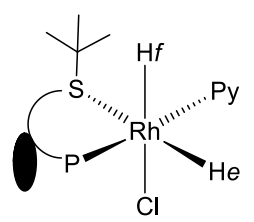

10

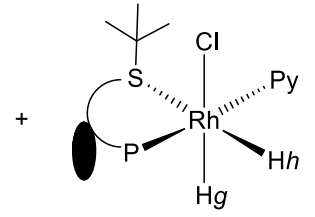

11
Scheme 6

When the pyridine excess was 75 fold, the experimental rate constant for the $\mathrm{H}_{\mathrm{e} \rightarrow \mathrm{c}}$ and $\mathrm{H}_{\mathrm{e} \rightarrow \mathrm{d}}$ processes $(\mathbf{1 0} \rightarrow \mathbf{9})$ were 75 indistinguishable at $31 \mathrm{~s}^{-1}$. In contrast the corresponding rate constant for $\mathrm{He}_{\mathrm{e} \rightarrow \mathrm{a}}$ and $\mathrm{H}_{\mathrm{e} \rightarrow \mathrm{b}}(\mathbf{1 0} \rightarrow \mathbf{8})$ was zero, as was mutual $\mathrm{He}_{\mathrm{e}}$ $\mathrm{H}_{\mathrm{f}}$ interchange (10). These values reduce from $31 \mathrm{~s}^{-1}$ to $20 \mathrm{~s}^{-1}$ to 3 $\mathrm{s}^{-1}$ as the pyridine excess falls from 75 fold through 42 fold to 15 fold. Hence this process is [py] dependent. Concerning the $\mathbf{9 \rightarrow 1 0}$ 80 process, the $\mathrm{H}_{\mathrm{c} \rightarrow \mathrm{e}}$ rate constant is $0.41 \mathrm{~s}^{-1}$, and the $\mathrm{H}_{\mathrm{c} \rightarrow \mathrm{f}}$ rate has a similar value. The corresponding rates for the $\mathbf{9} \rightarrow \mathbf{8}$ process are slightly smaller than those found when $\mathbf{2}$ is employed $\left(\mathrm{H}_{\mathrm{c} \rightarrow \mathrm{a}}\right.$ and $\mathrm{H}_{\mathrm{c} \rightarrow \mathrm{b}}$ are again similar at $0.1 \mathrm{~s}^{-1} v$ s. $0.16 \mathrm{~s}^{-1}$ for 2 ). The new rate constants for $\mathbf{8} \rightarrow \mathbf{9}$ with hydride position retention are zero when 851 is the precursor and $1.1 \mathrm{~s}^{-1}$ when $\mathbf{2}$ is employed. 8 does, however, form 10 with rate constants $1.3 \mathrm{~s}^{-1}$ for $\mathrm{H}_{\mathrm{a} \rightarrow \mathrm{f}}$ and zero for $\mathrm{H}_{\mathrm{a} \rightarrow \mathrm{e}}$. The observed hydride site exchange rate constants at $273 \mathrm{~K}$ measured on sample $\mathbf{1}$ for different pyridine concentrations are reported in Table $\mathrm{S} 2$.

90

\section{In $\mathrm{CD}_{3} \mathrm{OD}$ in the presence of acetonitrile}

In a further study, a $d_{4}$-methanol sample of 1 containing $20 \mu \mathrm{L}$ of acetonitrile was prepared. No reaction of $\mathbf{1}$ with $\mathrm{H}_{2}$ was evident until $273 \mathrm{~K}$. At this point, the corresponding ${ }^{1} \mathrm{H}$ NMR 95 spectrum contained two PHIP polarized hydride peaks at $\delta-14.5$ and -17.6. These hydride signals again appear as simple anti- 
phase doublets with additional phosphorus and rhodium couplings (Figure 4 ). The signal at $\delta-14.5$ exhibits a $\mathrm{J}_{\mathrm{HH}}$ coupling of $11 \mathrm{~Hz}$, a $J_{\mathrm{HP}}$ coupling of $20 \mathrm{~Hz}$ and a $\mathrm{J}_{\mathrm{RhH}}$ coupling of $21 \mathrm{~Hz}$ while the corresponding splittings of the $\delta$-17.6 signal are 12, 17 ${ }_{5} \mathrm{~Hz}$ and $20 \mathrm{~Hz}$ respectively. In the corresponding ${ }^{1} \mathrm{H}-{ }^{31} \mathrm{P}$ HMQC NMR spectrum, the $\delta-14.5$ signal and the $\delta-17.2$ signal proved to couple to a single ${ }^{31} \mathrm{P}$ centre located at $\delta 47.6$ which exhibited a $\mathrm{J}_{\mathrm{RhP}}$ splitting of $148 \mathrm{~Hz}$. These results suggest that hydrogenation of $\mathbf{1}$ in the presence of acetonitrile selectively forms the $\mathrm{MeCN}$ 10 analogue (12) of $\mathbf{8}$ (Scheme 7). There are a number of similarities between these data and those of $\mathbf{8}$. For example, all the couplings suggest a cis $\mathrm{PH}$ ligand arrangement and the chemical shifts are reflective of hydride ligands trans to sulfur and nitrogen. The coordination of $\mathrm{MeCN}$ has therefore the same effect as that of 15 pyridine in reducing the hydride acidity and reducing the speed of the $\mathrm{H} / \mathrm{D}$ exchange between $\mathrm{H}_{2}$ and the solvent.
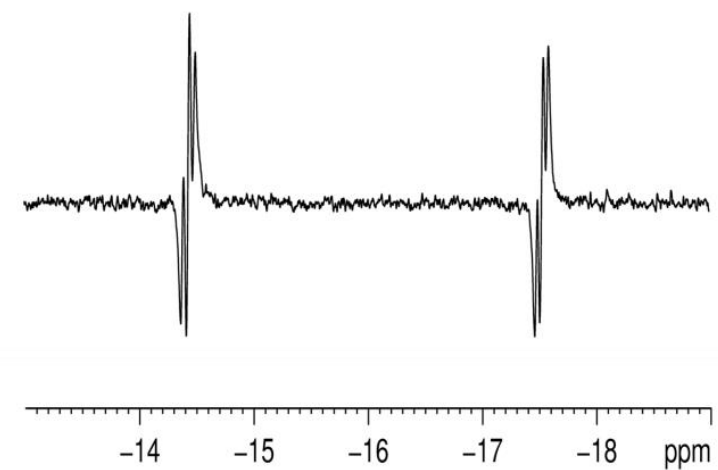

Figure 4. $p-\mathrm{H}_{2}$ enhanced ${ }^{1} \mathrm{H}$ NMR spectrum showing the hydride region of $\mathbf{1 2}$ observed during reaction of $\mathbf{1}$ in $\mathrm{d}_{4}$-methanol with $p-\mathrm{H}_{2}$ and acetonitrile 20 at $273 \mathrm{~K}$.

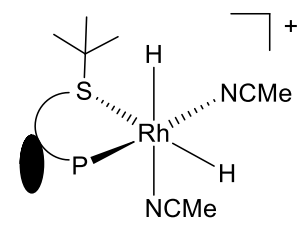

12

Scheme 7

\section{Hydrogenation Studies}

25 We have also explored the activity of these systems as hydrogenation catalysts. When a $d_{4}$-methanol sample of $\mathbf{1}$ containing $20 \mu \mathrm{l}$ (75 equiv) of pyridine and diphenylacetylene was examined at $258 \mathrm{~K}$, limited hydrogenation was evident and strongly enhanced signals for $\mathbf{8 , 9}, \mathbf{1 0}$ and $\mathbf{1 1}$ were visible which 30 exceed those in the analogous experiment without the alkyne. Under these conditions at $258 \mathrm{~K}$ the ratio of the $p-\mathrm{H}_{2}$ enhanced hydride signals of $\mathbf{8}$ and $\mathbf{9}$ was now 1:3.8. In contrast, when a similar sample was examined without pyridine, more rapid, but still slow, hydrogenation of diphenylacetylene occurs; signals for 35 both cis and trans stilbene are evident. These signals appear in an OPSY measurement which was used to detect only protons that were previously located in a single molecule of $p-\mathrm{H}_{2}$. No hydride signals were observed during these measurements.
When hydrogenation of the more reactive substrate 40 phenylacetylene by $\mathbf{1}$ was examined in $d_{4}$-methanol using $p-\mathrm{H}_{2}$, PHIP polarized signals could be readily seen for the styrene product at $263 \mathrm{~K}$ when no pyridine was present. No hydride signals still visible however in this experiment. In contrast, when a 10-fold excess of phenylacetylene and acetonitrile was added 45 there was evidence for both the formation of $\mathbf{1 2}$ and the hydrogenation of phenylacetylene.

\section{(b) DFT calculations}

On the basis of the presented experimental evidence, $\mathrm{H}_{2}$ is able to hydrogenate the COD ligand in compounds $\mathbf{1}$ and $\mathbf{2}$ in $\mathrm{MeOH}$, 50 presumably yielding a $\left[\mathrm{Rh}(\mathrm{P}, \mathrm{S} t \mathrm{Bu})(\mathrm{MeOH})_{2}\right]^{+}$product (4). However, any further oxidative addition of $\mathrm{H}_{2}$ to yield a putative dihydride product $\left[\mathrm{Rh}(\mathrm{H})_{2}\left(\mathrm{P}, \mathrm{S}{ }^{t} \mathrm{Bu}\right)(\mathrm{MeOH})_{2}\right]^{+}(\mathbf{5})$ would not be evidenced by ${ }^{1} \mathrm{H}$ NMR if there was rapid $\mathrm{H} / \mathrm{D}$ exchange as suggested. On the other hand, further $\mathrm{H}_{2}$ oxidative addition takes 55 place in the presence of py or $\mathrm{MeCN}$ to produce observable dihydridorhodium(III) species. A first question addressed by the computation tool was to explore the relative stability of the $\left[\mathrm{Rh}\left(\mathrm{P}, \mathrm{S}^{t} \mathrm{Bu}\right) \mathrm{L}_{2}\right]^{+}(\mathrm{L}=\mathrm{MeOH}, \mathrm{py}, \mathrm{MeCN})$ complexes and their ability to oxidatively add $\mathrm{H}_{2}$, as well as defining the relative 60 stability of all possible product isomers, see Scheme 8. The associated calculations were carried out using either the B3LYP functional or the M06 functional.

The hypothetical replacement of the COD ligand in $\left[\mathrm{Rh}\left(\mathrm{P}, \mathrm{S}^{t} \mathrm{Bu}\right)(\mathrm{COD})\right]^{+}(\mathbf{2})$ with two L donors to yield $\mathbf{I}^{\mathbf{L}}$ (without ${ }_{65}$ COD hydrogenation) was found at the B3LYP level as endoergic when $\mathrm{L}=\mathrm{MeOH}(\Delta \mathrm{E}=15.4 \mathrm{kcal} / \mathrm{mol}, \Delta \mathrm{G}=24.7 \mathrm{kcal} / \mathrm{mol})$ and more favourable for the other two ligands $(\Delta \mathrm{E} / \Delta \mathrm{G}$ are $-6.4 /+4.4$ $\mathrm{kcal} / \mathrm{mol}$ for $\mathrm{L}=$ py and $-1.5 /+6.0$ for $\mathrm{L}=\mathrm{MeCN})$. However, in consideration of the energy gain of the COD hydrogenation 70 process $(\Delta \mathrm{E}=-34.4$ or $\Delta \mathrm{G}=-18.5 \mathrm{kcal} / \mathrm{mol}$ for the hydrogenation to cyclooctene; $\Delta \mathrm{E}=-64.3$ or $\Delta \mathrm{G}=-33.1 \mathrm{kcal} / \mathrm{mol}$ for the hydrogenation to cyclooctane), all the underlying reactions become favourable.

The oxidative addition of $\mathrm{H}_{2}$ was also found to be energetically 75 favourable for all three ligand systems, as shown by the data collected in Table 2. It should be noted that while the gas phase free energies are positive, the computed values do not take into account stabilisation from solvation and the partial quenching of translational and rotational modes in the condensed phase. 80 Furthermore, the hydride complexes were observed at low temperatures, where the detrimental effect of the positive T $\Delta S$ contribution is smaller (for instance, the calculated $\Delta \mathrm{G}$ for the oxidative addition to $\mathbf{I}^{\mathbf{p y}}$ to yield $\mathbf{V}^{\mathbf{p y}}$ at the M06 level decreased from +6.0 to $+4.9 \mathrm{kcal} / \mathrm{mol}$ when applying the thermochemical 85 corrections at $253 \mathrm{~K}$ instead of $298 \mathrm{~K}$ ) and indeed the hydride resonances were lost upon warming the NMR tubes to higher temperatures (vide supra). For the pyridine system, the calculations have also been carried out at the M06 level, showing a slightly less favourable process. We note that the oxidative 90 addition process for $\mathrm{L}=\mathrm{MeOH}$ is predicted by these calculations to be more favourable than for the other two ligands. Therefore, failure to observe the corresponding hydride resonances by ${ }^{1} \mathrm{H}$ NMR during the experiments appears indeed attributable to the accumulation of deuteride species by rapid H/D exchange. The 95 dihydride complex is, though, at least sufficiently accessible to allow the H/D process to take place as suggested in Scheme 3 . 


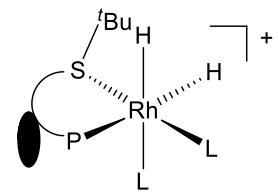

$\mathrm{H}$ anti Fc

II $^{\mathbf{L}}$

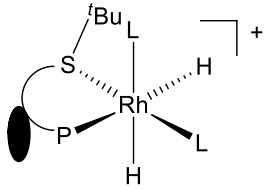

$\mathrm{H}$ syn Fc

III $^{\mathrm{L}}$

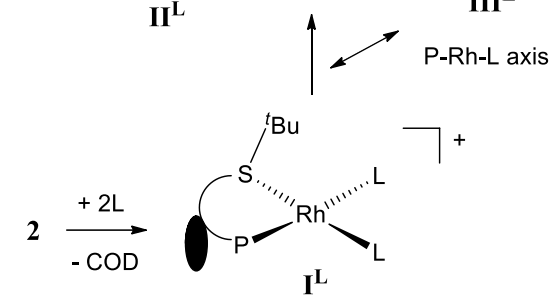

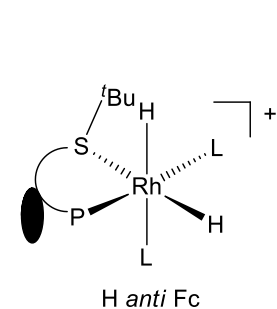

IV ${ }^{\mathbf{L}}$
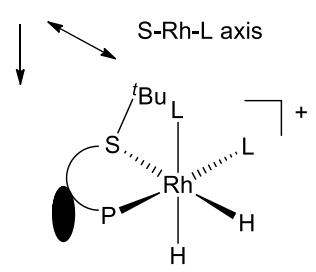

$\mathrm{H}$ syn Fc

$\mathbf{V}^{\mathbf{L}}$
Scheme 8

Table 2. Relative gas phase energies $\mathrm{E}$ (free energies $\mathrm{G}$ in parentheses) in $\mathrm{kcal} / \mathrm{mol}$ for the products of $\mathrm{H}_{2}$ oxidative addition to $\mathbf{I}^{\mathbf{L}}$.

\begin{tabular}{cccccc}
\hline $\mathbf{L}$ & Functional & $\mathbf{I I}^{\mathbf{L}}$ & $\mathbf{I I I}^{\mathbf{L}}$ & $\mathbf{I V}^{\mathbf{L}}$ & $\mathbf{V}^{\mathbf{L}}$ \\
\hline $\mathrm{MeOH}$ & B3LYP & $-8.5(+2.6)$ & $-10.5(+1.3)$ & $-14.1(-2.5)$ & $-17.6(-6.5)$ \\
py & B3LYP & $-4.5(+7.4)$ & $-4.9(+7.9)$ & $-10.1(+1.5)$ & $-10.0(+2.1)$ \\
py & M06 & $+4.5(+15.2)$ & $+2.2(+14.7)$ & $-2.5(+7.8)$ & $-3.5(+6.0)$ \\
$\mathrm{MeCN}$ & B3LYP & $-4.2(+5.6)$ & $-4.9(+6.0)$ & $-8.5(+1.7)$ & $-10.9(-0.1)$ \\
\hline
\end{tabular}

The computational results also suggest that the two isomers resulting from the $\mathrm{H}-\mathrm{H}$ addition across the $\mathrm{S}-\mathrm{Rh}-\mathrm{L}$ axis are energetically preferred independent on $\mathrm{L}$, in agreement with the assignment of the NMR spectra. The stereochemistry of structure ${ }_{10} \mathbf{I V}$ corresponds to that of $\mathbf{8}$ and $\mathbf{1 2}$ and $\mathbf{V}$ corresponds to $\mathbf{9}$. Structure $\mathbf{V}^{\mathbf{p y}}$ is slightly less stable than $\mathbf{I V}^{\mathbf{p y}}$ at the B3LYP level, but more stable at the M06 level in agreement with the NMR evidence. For $\mathrm{L}=\mathrm{MeCN}$ and $\mathrm{MeOH}$, the calculations also indicate greater stability for isomer $\mathbf{V}^{\mathbf{L}}$, even at the B3LYP level, 15 whereas the NMR assignment indicates that the observed compound $\mathbf{1 2}$ has the same configuration as IV.

A second question addressed by the DFT study is the mechanism for the $\mathrm{H}$-site exchange in the two observed isomers for the pyridine systems ( $\mathbf{8}$ and $\mathbf{9}$, or $\mathbf{I V}^{\mathbf{p y}}$ and $\mathbf{V}^{\mathbf{p y}}$ ). The simplest 20 way to imagine the isomerisation process, given the known strong trans labilizing effect of the hydride ligands, involves dissociation of a neutral donor placed trans to a hydride ligand (either the sulphur donor of the bidentate $\mathrm{P}, \mathrm{S}$ ligand or a pyridine molecule) and rearrangement of the coordination sphere, as 25 shown in Scheme 9 for the specific case of thioether dissociation. The putative 5-coordinate intermediate $\mathbf{A}$ would then rearrange to its diastereoisomer $\mathbf{B}$ (same chirality at ferrocene and inverted chirality at rhodium) by either concerted hydride migration and rotation of the P,S ligand or via tautomerization to the dihydrogen 30 complex $\mathbf{C}$ followed by $\mathrm{P}, \mathrm{S}$ rotation to yield the rotamer $\mathbf{D}$.
Hydride site exchange can be envisaged by rotation of the dihydrogen ligand in the intermediates $\mathbf{C}$ and $\mathbf{D}$. The observation of such a ligand exchange process by NMR is not inconsistent provided the lifetime of the rapidly relaxing dihydrogen form is 35 short. $^{23,24}$
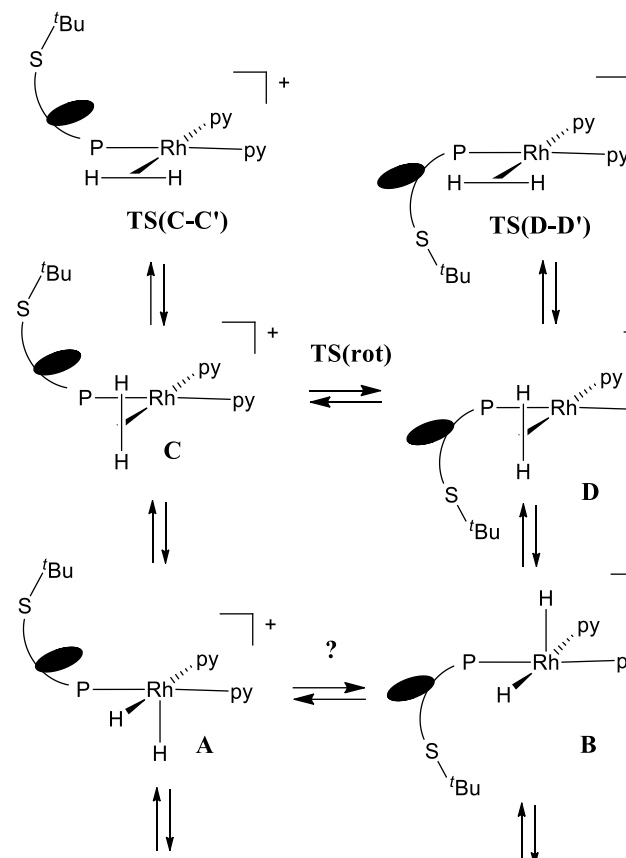

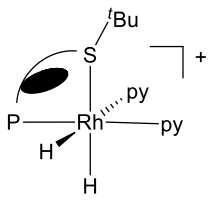

IV ${ }^{\text {py }}$
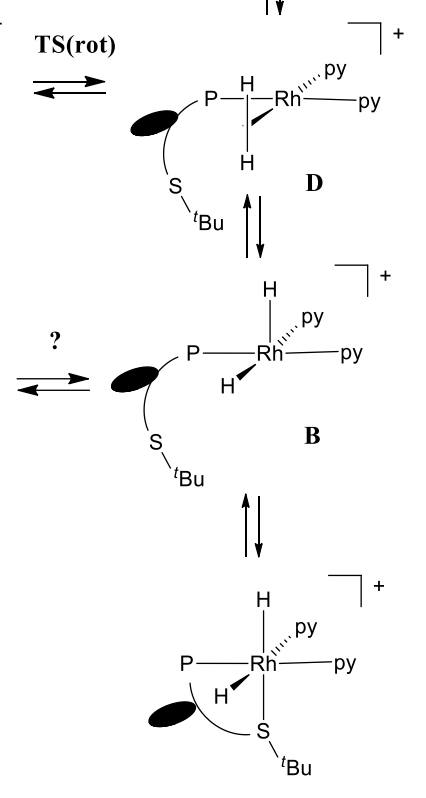

Vpy
Scheme 9

All calculations of this pathway were carried out with the M06 functional, since this is expected to better handle the long range 40 dispersion interactions involved in the ligand dissociation processes. They show that pyridine dissociation is less favourable than the P,S ligand thioether arm dissociation. The most favourable dihydride complex resulting from py dissociation, $\left[\left(\mathrm{P}, \mathrm{S}^{t} \mathrm{Bu}\right) \mathrm{Rh}(\mathrm{H})_{2}(\mathrm{py})\right]^{+}$, is located at $29.7 \mathrm{kcal} / \mathrm{mol}$ from $\mathbf{V}^{\mathbf{p y}}$, 45 while the isomeric non-classical complex $\left[\left(\mathrm{P}, \mathrm{S}{ }^{t} \mathrm{Bu}\right) \mathrm{Rh}\left(\mathrm{H}_{2}\right)(\mathrm{py})\right]^{+}$ is more stable at only $18.3 \mathrm{kcal} / \mathrm{mol}$ from $\mathbf{V}^{\mathbf{p y}}$. However, the most stable dihydride complex resulting from dissociation of the thioether arm (B in Scheme 9) is only $12.4 \mathrm{kcal} / \mathrm{mol}$ from $\mathbf{V}^{\mathbf{p y}}$, with A being only slightly higher at $+14.7 \mathrm{kcal} / \mathrm{mol}$ and the 50 nonclassical isomers $\mathbf{C}$ and $\mathbf{D}$ are even more stabilized at +11.8 and $+8.3 \mathrm{kcal} / \mathrm{mol}$, respectively. Therefore, the isomerization pathway shown in Scheme 9 was fully explored. The results are summarized in Figure 5. Rearrangement of the classical to the nonclassical dihydrides occurs via localized transition states ${ }_{55} \mathbf{T S}_{\mathbf{A C}}$ and $\mathbf{T S}$ BD at +18.4 and $+16.2 \mathrm{kcal} / \mathrm{mol}$. A more direct pathway from $\mathbf{I V}^{\mathbf{p y}}$ to $\mathbf{C}$ and from $\mathbf{V}^{\mathbf{p y}}$ to $\mathbf{D}$ could not be found. The P,S ligand rotation pathway involved in the interconversion of $\mathbf{C}$ and $\mathbf{D}$ was not straightforward to investigate for the location of a stationary point, but a manual scan of the dihedral N-Rh-P-C 
angle (see Figure S4) led to the identification a new local minimum corresponding to a new rotational intermediate $\mathbf{E}$ and two maxima, the highest point being $4.3 \mathrm{kcal} / \mathrm{mol}$ higher than $\mathbf{D}$ $\left(+12.6 \mathrm{kcal} / \mathrm{mol}\right.$ from $\left.\mathbf{V}^{\mathbf{p y}}\right)$. The search for a more direct pathway 5 from $\mathbf{A}$ to $\mathbf{B}$ was unsuccessful. The barrier for site exchange was calculated for $\mathbf{D}$ and turned out rather low $(2.5 \mathrm{kcal} / \mathrm{mol}$, or + $10.8 \mathrm{kcal} / \mathrm{mol}$ from $\mathbf{V}^{\mathbf{p y}}$ ), lower than the barriers required to go back to the stable classical dihydride isomers.
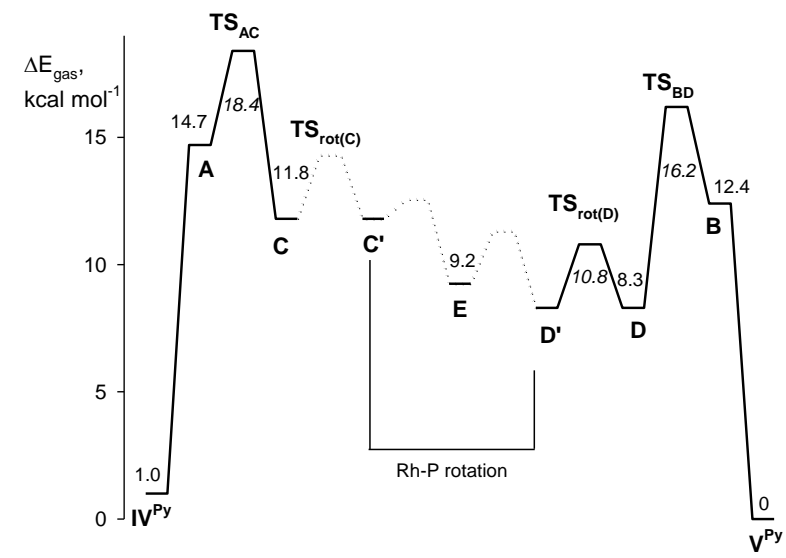

10

Figure 5. Energy profile (gas phase energies in $\mathrm{kcal} / \mathrm{mol}$ ) of the isomerization pathway of Scheme 9.

The results in Figure 5 are in agreement with certain experimental observations. Isomerization from $\mathbf{V}^{\mathbf{p y}}(\mathbf{9})$ to $\mathbf{I V}^{\mathbf{p y}}(\mathbf{8})$ requires transiting over the $\mathbf{T} \mathbf{S}_{\mathbf{A C}}$ barrier, whereas the site 15 exchange in $\mathbf{9}$ may occur by simple access of the nonclassical intermediate and facile $\mathrm{H}_{2}$ rotation, followed by the reverse pathway to $\mathbf{V}^{\mathbf{p y}}$ through the lower $\mathbf{T} \mathbf{S}_{\mathbf{B D}}$ barrier. This agrees with the faster site exchange relative to the $\mathbf{9} \rightarrow \mathbf{8}$ process. During the reverse isomerization of $\mathbf{I V}^{\mathbf{p y}}(\mathbf{8})$ to $\mathbf{V}^{\mathbf{p y}}(\mathbf{9})$, on the other hand, 20 once the highest $\mathbf{T} \mathbf{S}_{\mathbf{A C}}$ barrier is passed and the intermediate $\mathbf{C}$ is generated, the isomerization process through $\mathrm{P}, \mathrm{S}$ ligand rotation and the lower energy $\mathbf{T S}_{\mathbf{B D}}$ occurs faster than the reverse generation of $\mathbf{I V}^{\mathbf{p y}}$, consistent with the fact that site exchange for $\mathbf{8}$ is not observed.

25 A most interesting experimental result is that the transformation of the minor isomer (8) into the major one (9) occurs preferentially as $\mathrm{H}_{a \rightarrow c}$ and $\mathrm{Hb}_{b \rightarrow \mathrm{d}}$ at low [py] but preferentially as $\mathrm{H}_{a \rightarrow d}$ and $\mathrm{H}_{b \rightarrow c}$ at high [py] (see Scheme 5). The former situation, according to Scheme 9, would be compatible 30 with a concerted pathway directly converting A to $\mathbf{B}$ without transiting through the nonclassical intermediate (arrows with question mark in Scheme 9) through a transition state at lower energy than $\mathbf{T} \mathbf{S}_{\mathbf{A C}}$ and $\mathbf{T S}$ BD. As stated above, such a pathway could not be located but we cannot exclude that it exists. At 35 greater pyridine concentrations, this pathway may be blocked by reversible coordination of pyridine to $\mathbf{A}$ and $\mathbf{B}$ while perhaps the excess pyridine could also assist a faster collapse of the two hydrides into the $\mathrm{H}_{2}$ ligand (for instance through the effect of $\mathrm{H}$ bonding).

40 Reversal of the relative rates of site exchange requires a new isomerisation pathway, resulting in selective migration of the axial $\mathrm{H}$ ligand in the square pyramidal geometry of $\mathbf{A}$ and $\mathbf{B}$ without moving the second $\mathrm{H}$ ligand in the equatorial plane. One attractive possibility for this transformation is a selective 45 deprotonation of the axial site in $\mathbf{A}$ by excess pyridine, which is the strongest base present in solution, to yield a square planar monohydride intermediate $\left[\mathrm{RhH}\left(\kappa^{1}-\mathrm{P}, \mathrm{S}\right)(\mathrm{py})_{2}\right]$, followed by reprotonation at the opposite face of the square plane to afford $\mathbf{B}$. This pathway is closely related to one of the proposed pathways 50 for the H/D exchange between $\mathrm{H}_{2}$ and solvent in pure $\mathrm{CD}_{3} \mathrm{OH}$ (through intermediates 5 and $\mathbf{6}$ of Scheme 3). No calculations were carried out, however, to confirm the feasibility of this pathway. The fact that this strong effect is not observed during the transformation of the minor isomer into the major one $(\mathbf{8} \rightarrow \mathbf{9})$ 55 is consistent with the need to overcome the smaller $\mathbf{T S}$ BD barrier in the first step to achieve the rapid site scrambling. Hence, if the transition state of the putative site-conserving concerted pathway is lower than $\mathbf{T} \mathbf{S}_{\mathbf{A C}}$ but higher or comparable to $\mathbf{T} \mathbf{S}_{\mathbf{B D}}$, then the site exchange would remain operative even at low pyridine ${ }_{60}$ concentration. For the same reason, a very large concentration of pyridine does not afford a selective site inversion because collapse to the nonclassical intermediate promotes non selective deprotonation.

\section{Conclusions}

${ }_{65}$ The present contribution has explored the precatalyst activation phase for hydrogenation processes carried out in alcohol solvents with $\left[\mathrm{Rh}(\text { diene })\left(\mathrm{LL}^{\prime}\right)\right]^{+}$systems, using $\left[\mathrm{Rh}(\mathrm{COD})\left(\mathrm{P}, \mathrm{S}^{t} \mathrm{Bu}\right)\right]^{+}$as a model compound. The COD ligand is removed by hydrogenation to yield a putative $\left[\mathrm{Rh}\left(\mathrm{P}, \mathrm{S}^{t} \mathrm{Bu}\right)\left(\mathrm{CH}_{3} \mathrm{OH}\right)_{2}\right]^{+}$complex which 70 promotes a very rapid $\mathrm{H} / \mathrm{D}$ exchange between $\mathrm{H}_{2}$ and the solvent, possibly via a dihydride species $\left[\mathrm{Rh}\left(\mathrm{P}, \mathrm{S}{ }^{t} \mathrm{Bu}\right)(\mathrm{H})_{2}\left(\mathrm{CH}_{3} \mathrm{OH}\right)_{2}\right]^{+}$that is accessible according to the DFT calculations. Addition of $\mathrm{L}$ (pyridine or $\mathrm{MeCN}$ ) slows down this exchange, allowing the observation of diasteromeric dihydride species at low 75 temperature. Evidence has also been obtained for equilibrium deprotonation of these cationic dihydride complexes in the presence of strong bases (e.g. excess pyridine). This phenomenon is presumably linked to the need of a strong base promoter for the catalytic action of these compounds and of the iridium analogues 80 in the ionic hydrogenation of polar unsaturated substrates. ${ }^{14,22}$

\section{Acknowledgements}

The York authors would like to thank the EPSRC (grant no. EP/G009546/1) for funding. The Toulouse and Moscow authors are grateful to the CNRS (Centre National de la Recherche ${ }_{85}$ Scientifique) and the RFBR (Russian Foundation for Basic Research) for support through the GDRI (Groupe de Recherche Internationale) "Homogeneous catalysis for Sustainable Development" and the RFBR grants no. 12-03-93112, 12-0331326, and 12-03-33018. We are also grateful to the IUF (Institut 90 Universitaire de France) for additional funding and to the CINES (Centre Informatique National de l'Enseignement Supérieur) and the CICT (Centre Interuniversitaire de Calcul de Toulouse, project CALMIP) for granting free computational time. EMK thanks the Embassy of France in Moscow for a Ph.D. grant.

\section{${ }_{95}$ Notes and references}


${ }^{a}$ CNRS, LCC (Laboratoire de Chimie de Coordination), 205 route de Narbonne, BP 44099, F-31077 Toulouse Cedex 4, France CNRS. Fax: +33-561553003; Tel: +33-561333173; E-mail: rinaldo.poli@lcctoulouse.fr, eric.manoury@lcc-toulouse.fr.

$5^{b}$ Université de Toulouse, UPS, INPT, F-31077 Toulouse Cedex 4, France

${ }^{c}$ A. N. Nesmeyanov Institute of Organoelement Compounds, Russian Academy of Sciences, Vavilov Street 28, 119991 Moscow, Russia; Fax: +7-499-1355085; Tel:+7-499-1356448; E-mail: nataliabelk@ineos.ac.ru ${ }^{d}$ Centre for Hyperpolarisation in Magnetic Resonance, Department of

${ }_{10}$ Chemistry, University of York, Heslington, York, YO10 5NY, UK. Fax: +44-1904-322516; Tel: +44-1904322564;E-mail: simon.duckett@york.ac.uk

${ }^{e}$ Institut Universitaire de France, 103, bd Saint-Michel, 75005 Paris, France.

$15 \dagger$ Electronic Supplementary Information (ESI) available: sample preparation details for the parahydrogen NMR experiments, selected NMR spectra, description of the EXSY experiments of hydride exchange, figures of DFT optimized geometries and full table of cartesian coordinates for the DFT optimized structures. See 20 DOI: $10.1039 / \mathrm{b} 000000 \mathrm{x} /$

1. J. A. Osborn, F. H. Jardine, J. F. Young and G. Wilkinson, J. Chem. Soc. A, 1966, 1711-1732.

2. R. H. Crabtree, H. Felkin and G. E. Morris, J. Organomet. Chem., 1977, 141, 205-215.

25 3. S.-M. Lu, X.-W. Han and Y.-G. Zhou, Adv. Synth. \& Catal., 2004, 346, 909-912.

4. S.-F. Zhu, J.-B. Xie, Y.-Z. Zhang, S. Li and Q.-L. Zhou, J. Am. Chem. Soc., 2006, 128, 12886-12891.

5. T. Imamoto, N. Iwadate and K. Yoshida, Org. Lett., 2006, 8, 2289302292

6. M. N. Cheemala and P. Knochel, Org. Lett., 2007, 9, 3089-3092.

7. G. Hou, F. Gosselin, W. Li, C. McWilliams, Y. Sun, M. Weisel, P. D. O'Shea, C.-y. Chen, I. W. Davies and X. Zhang, J. Am. Chem. Soc., 2009, 131, 9882-9883.

358 . W. J. Tang, J. Tan, L. J. Xu, K. H. Lam, Q. H. Fan and A. S. C. Chan, Adv. Synth. Catal., 2010, 352, 1055-1062.

9. W. Tang, Y. Sun, L. Xu, T. Wang, Q. Fan, K.-H. Lam and A. S. C. Chan, Org. Biomol. Chem., 2010, 8, 3464-3471.

10. D. Cartigny, T. Nagano, T. Ayad, J.-P. Genet, T. Ohshima, K.

40 Mashima and V. Ratovelomanana-Vidal, Adv. Synth. Catal., 2010, 352, 1886-1891.

11. R. Dorta, D. Broggini, R. Stoop, H. Ruegger, F. Spindler and A. Togni, Chem. Eur. J., 2004, 10, 267-278.

12. H.-U. Blaser, Adv. Synth. Catal., 2002, 344, 17-31.

45 13. L. Routaboul, S. Vincendeau, J.-C. Daran and E. Manoury, Tetrahedron: Asymmetry, 2005, 16, 2685-2690.

14. E. Le Roux, R. Malacea, E. Manoury, R. Poli, L. Gonsalvi and M. Peruzzini, Adv. Synth. \& Catal., 2007, 349, 309-313.

15. R. Malacea, J.-C. Daran, S. B. Duckett, J. P. Dunne, C. Godard, E.

$50 \quad$ Manoury, R. Poli and A. C. Whitwood, Dalton, 2006, 33503359.

16. R. Malacea, E. Manoury, L. Routaboul, J.-C. Daran, R. Poli, J. P. Dunne, A. C. Withwood, C. Godard and S. B. Duckett, Eur. J. Inorg. Chem., 2006, 1803-1816.

55 17. A. Preetz, H. J. Drexler, C. Fischer, Z. Dai, A. Borner, W. Baumann, A. Spannenberg, R. Thede and D. Heller, Chem. Eur. J., 2008, 14, 1445-1451.

18. A. Preetz, C. Fischer, C. Kohrt, H. J. Drexler, W. Baumann and D. Heller, Organometallics, 2011, 30, 5155-5159.
60 19. E. Alberico, W. Baumann, J. G. de Vries, H. J. Drexler, S. Gladiali, D. Heller, H. J. W. Henderickx and L. Lefort, Chem. Eur. J., 2011, 17, 12683-12695.

20. C. Fischer, S. Schulz, H. J. Drexler, C. Selle, M. Lotz, M. Sawall, K. Neymeyr and D. Heller, ChemCatChem, 2012, 4, 81-88.

65 21. E. M. Kozinets, O. Koniev, O. A. Filippov, J.-C. Daran, R. Poli, E. S. Shubina, N. V. Belkova and E. Manoury, Dalton Trans., 2012, 41, 11849-11859.

22. E. M. Kozinets, N. V. Belkova, E. S. Shubina, R. Poli and E. Manoury, Russ. Chem. Bull., 2013, 750-756.

70 23. S. B. Duckett and R. E. Mewis, Acc. Chem. Res., 2012, 45, $1247-$ 1257.

24. R. A. Green, R. W. Adams, S. B. Duckett, R. E. Mewis, D. C. Williamson and G. G. R. Green, Progr. Nucl. Magn. Res. Spectr., 2012, 67, 1-48.

75 25. C. R. Bowers and D. P. Weitekamp, J. Am. Chem. Soc., 1987, 109, 5541-5542.

26. T. C. Eisenschmid, R. U. Kirss, P. P. Deutsch, S. I. Hommeltoft, R. Eisenberg, J. Bargon, R. G. Lawler and A. L. Balch, J. Am. Chem. Soc., 1987, 109, 8089-8091.

80 27. K. Golman and J. S. Petersson, Acad. Radiol., 2006, 13, 932-942.

28. D. Blazina, S. B. Duckett, P. J. Dyson, B. F. G. Johnson, J. A. B. Lohman and C. J. Sleigh, J. Am. Chem. Soc., 2001, 123, 97609768.

29. D. Blazina, S. Duckett, P. Dyson and J. Lohmann, Chem. Eur. J., 85 2003, 9, 1046-1061.

30. M. A. M. Al-Ibadi, S. B. Duckett and J. E. McGrady, Dalton Trans., 2012, 41, 4618-4625.

31. D. Schott, C. J. Sleigh, J. P. Lowe, S. B. Duckett, R. J. Mawby and M. G. Partridge, Inorg. Chem., 2002, 41, 2960-2970.

90 32. D. Schott, P. Callaghan, J. Dunne, S. B. Duckett, C. Godard, J. M. Goicoechea, J. N. Harvey, J. P. Lowe, R. J. Mawby, G. Müller, R. N. Perutz, R. Poli and M. K. Whittlesey, J. Chem. Soc., Dalton Trans., 2004, 3218-3224.

33. J. Lopez-Serrano, S. B. Duckett, S. Aiken, K. Q. Almeida Lenero, E. 95 Drent, J. P. Dunne, D. Konya and A. C. Whitwood, J. Am. Chem. Soc., 2007, 129, 6513-6527.

34. J. Lopez-Serrano, S. B. Duckett and A. Lledós, J. Am. Chem. Soc., 2006, 128, 9596-9597.

35. B. Eguillor, P. J. Caldwell, M. C. R. Cockett, S. B. Duckett, R. O. John, J. M. Lynam, C. J. Sleigh and I. Wilson, J. Am. Chem. Soc., 2012, 134, 18257-18265.

36. S. B. Duckett and C. J. Sleigh, Progr. Nucl. Magn. Res. Spectr., 1999, 34, 71-92.

37. M. J. Frisch, G. W. Trucks, H. B. Schlegel, G. E. Scuseria, M. A. 105 Robb, J. R. Cheeseman, G. Scalmani, V. Barone, B. Mennucci, G. A. Petersson, H. Nakatsuji, M. Caricato, X. Li, H. P. Hratchian, A. F. Izmaylov, J. Bloino, G. Zheng, J. L. Sonnenberg, M. Hada, M. Ehara, K. Toyota, R. Fukuda, J. Hasegawa, M. Ishida, T. Nakajima, Y. Honda, O. Kitao, H. Nakai, T. Vreven, J. Montgomery, J. A., J. E. Peralta, F. Ogliaro, M. Bearpark, J. J. Heyd, E. Brothers, K. N. Kudin, V. N. Staroverov, R. Kobayashi, J. Normand, K. Raghavachari, A. Rendell, J. C. Burant, S. S. Iyengar, J. Tomasi, M. Cossi, N. Rega, N. J. Millam, M. Klene, J. E. Knox, J. B. Cross, V. Bakken, C. Adamo, J. Jaramillo, R. Gomperts, R. E. 
Stratmann, O. Yazyev, A. J. Austin, R. Cammi, C. Pomelli, J. W. Ochterski, R. L. Martin, K. Morokuma, V. G. Zakrzewski, G. A. Voth, P. Salvador, J. J. Dannenberg, S. Dapprich, A. D. Daniels, Ö. Farkas, J. B. Foresman, J. V. Ortiz, J. Cioslowski and D. J. Fox, Gaussian 09, Revision A.01, Gaussian, Inc., Wallingford CT, 2009.

38. A. D. Becke, J. Chem. Phys., 1993, 98, 5648-5652.

39. C. T. Lee, W. T. Yang and R. G. Parr, Phys. Rev. B, 1988, 37, 785789.

10 40. Y. Zhao and D. G. Truhlar, Theor. Chem. Acc., 2008, 120, 215-241.

41. D. Andrae, U. Haussermann, M. Dolg, H. Stoll and H. Preuss, Theor. Chim. Acta, 1990, 77, 123-141.

42. U. Haussermann, M. Dolg, H. Stoll, H. Preuss, P. Schwerdtfeger and R. M. Pitzer, Mol. Phys., 1993, 78, 1211-1224.

15 43. W. Kuchle, M. Dolg, H. Stoll and H. Preuss, J. Chem. Phys., 1994, 100, 7535-7542.

44. T. Leininger, A. Nicklass, H. Stoll, M. Dolg and P. Schwerdtfeger, J. Chem. Phys., 1996, 105, 1052-1059.

45. A. W. Ehlers, M. Boehme, S. Dapprich, A. Gobbi, A. Hoellwarth, V. 20 Jonas, K. F. Koehler, R. Stegmann, A. Veldkamp and G. Frenking, Chem. Phys. Lett., 1993, 208, 111-114.

46. J. Fritsch and G. Zundel, J. Phys. Chem., 1981, 85, 556-561.

47. R. Kramer and G. Zundel, J. Chem. Soc., Faraday Trans., 1990, 86, 301-305.

25 48. M. Martin, E. Sola, O. Torres, P. Plou and L. A. Oro, Organometallics, 2003, 22, 5406-5417. 